\title{
Identification of a novel QTL contributing to rust resistance in Eucalyptus
}

\author{
Bruno M Lima1", Juliana EC Teixeira ${ }^{2}$, Rodrigo Gazaffi ${ }^{1}$, Antonio AF Garcia' ${ }^{1}$, Dario Grattapaglia ${ }^{3}$, Raphaelle KD Valle ${ }^{4}$ \\ , Luis EA Camargo ${ }^{4}$ \\ From IUFRO Tree Biotechnology Conference 2011: From Genomes to Integration and Delivery \\ Arraial d'Ajuda, Bahia, Brazil. 26 June - 2 July 2011
}

\section{Background}

The genus Eucalyptus has many species that are well adapted to a wide range of environmental conditions in Brazil. However, in some areas diseases are a limiting factor, among which the Eucalyptus rust caused by Puccinia psidii Winter stands out as a destructive pathogen of the Myrtacea. The growth of plants with high levels of infection is severely compromised and these plants end up being dominated by adjacent plants which ultimately leads to their death. The most efficient method to control the disease is through the use of resistant genotypes. A major effect rust resistance QTL has already been identified [1,2], however a residual variance stays unexplained. In this context, our study aimed to identify genomic regions containing quantitative resistance loci to rust based on segregation data of a $S_{1}$ progeny from an inter-specific (Eucalyptus grandis $\mathrm{x} E$. urophylla) resistant clone.

\section{Material and methods}

The progeny used in this study was generated by the breeding program of Fibria and is composed of $90 S_{1}$ trees from the self-pollination of an E. grandis $\mathrm{x} E$. urophylla hybrid tree. This hybrid (VCP-R) is heterozygous for a rust resistance locus [3] and highly resistant to rust. The plants were evaluated at two different sites with high incidence of rust starting in November 2005. Four disease severity evaluations were made at 90, 120, 150 and 180 days after planting by scoring the levels of disease using a four-score severity scale. Scores were used to calculate the area under the disease progress curve (AUDPC) for each plant and for BLUPs estimation.

\footnotetext{
* Correspondence: bmlima@esalq.usp.br

'Departamento de Genética, Universidade de São Paulo - ESALQ/USP, Piracicaba, SP, Brazil

Full list of author information is available at the end of the article
}

Genomic DNA was CTAB extracted from health young leaves and used in PCR amplifications of 121 microsatellite, 20 TRAP and 38 AFLP markers (totalizing 179 markers). The Onemap software [4] was used in linkage analysis. The estimated BLUPs were used in QTL mapping [5]. The QTLs were mapped by interval mapping (IM) and composite interval mapping (CIM).

\section{Results}

Linkage analysis resulted in 11 linkage groups with 160 linked markers. The identity of the groups were as in [6]based on common microsatellite loci as references. The length of the map was $1075 \mathrm{cM}$ with an average distance of $6.7 \mathrm{cM}$. IM analysis identified one QTL in linkage group $3(\mathrm{LOD}=7.7)$ with a large phenotypic effect that accounted for $28.5 \%$ of the variation (fig. 1). The negative additive effect was significant $(\mathrm{p}=0.05)$, without dominance effects. QTL was located $1.6 \mathrm{cM}$ from SSR EMBRA049 and $5.8 \mathrm{cM}$ from AFLP E08M18_250. The CIM analysis mapped two QTLs, both located in linkage group 3. The peak LOD score $(\mathrm{LOD}=10.3)$ of $\mathrm{QTL}_{1}$, which explained $39.5 \%$ of the phenotypic variation, mapped in the same interval of the QTL identified in the IM analysis. It was located close to Embra049 (1.6 cM) and presented significant negative additive effects and no significant dominance effect. The second QTL $\left(\mathrm{QTL}_{2}\right)$, with $\mathrm{LOD}=3.4$, had a relative lower phenotypic effect (6,9\%), mapped $3.1 \mathrm{cM}$ close to the AFLP marker E08M18_300 AFLP. However, differently than $\mathrm{QTL}_{1}, \mathrm{QTL}_{2}$ presented both additive and dominance effects.

\section{Conclusions}

The use of the AUDPC permitted to transform discrete variables (symptoms scores) into a continuous variable, which gives greater power in QTL detection. The effect 


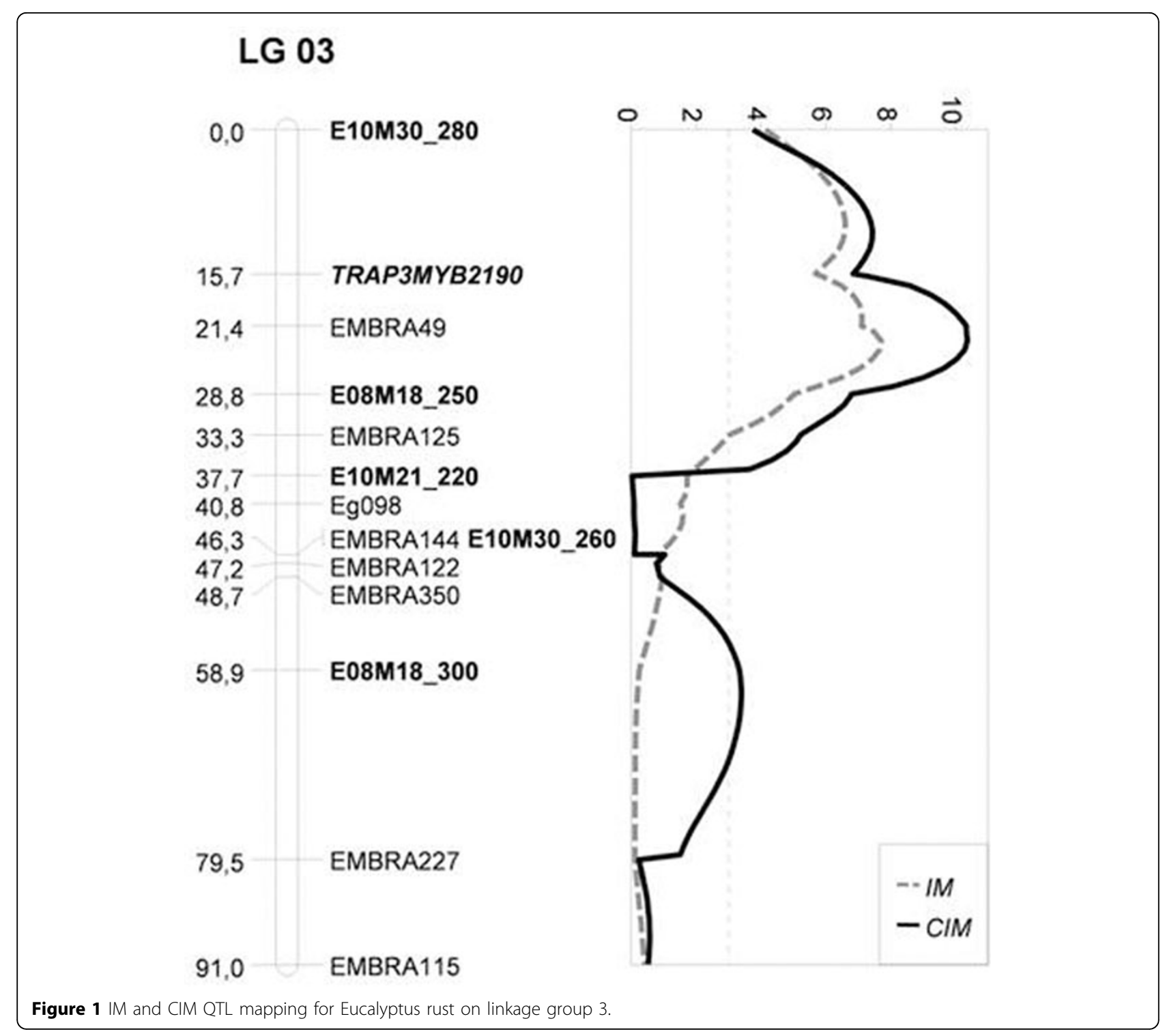

of the reduced size of the $S_{1}$ progeny in QTL detection was compensated by the BLUPs analysis, which considers only the genetic variation in QTL localization. QTL mapping was done by two different approaches (IM and CIM) that presented contrasting results. The non detection of $\mathrm{QTL}_{2}$ in the IM analysis was probably due to the limitations of the method (e.g., non-independence in different intervals when there are more than one QTL and low precision of the position by the presence of linked QTLs). Previous studies on the inheritance of resistance to rust in eucalyptus identified a locus with large phenotypic effect, but also pointed to the existence of minor effects $[1,2]$. Our results confirm the hypothesis of the presence of at least one minor effect locus, by data analysis in quantitative approach and CIM, as never used before in Eucalyptus rust resistance mapping. This work revealed the existence of a second rust resistance locus in addition to one with large effect locus previously mapped in linkage group 3. The identification of markers linked to resistance loci gives perspectives of MAS of resistant genotypes, which is desirable in the case of this disease due to the technical and economical difficulties of selecting resistant genotypes based solely on phenotypes since this biotrophic requires large areas and skilled labor. In addition this study opens possibilities for the positional cloning of the resistance genes together with the availability of the genome sequence of eucalyptus.

Financial support.Fibria, CNPq, CAPES, ESALQ-USP. 


\section{Author details}

'Departamento de Genética, Universidade de São Paulo - ESALQ/USP,

Piracicaba, SP, Brazil. ${ }^{2}$ Fibria, Jacareí, SP, Brazil. ${ }^{3}$ EMBRAPA Recursos Genéticos e Biotecnologia, Brazilia, DF, Brazil. ${ }^{4}$ Departamento de Fitopatologia e

Nematologia, Universidade de São Paulo - ESALQ/USP, Piracicaba, SP, Brazil.

Published: 13 September 2011

\section{References}

1. Junghans DT, Alfenas AC, Brommonschenkel SH, Oda S, Mello EJ, Grattapaglia D: Resistance to rust (Puccinia psidii Winter) in Eucalyptus: mode of inheritance and mapping of a major gene with RAPD markers. Theoretical and Applied Genetics 2003, 108:175-180.

2. Mamani EMC, Bueno NW, Faria DA, Guimaraes LMS, Lau D, Alfenas AC, Grattapaglia D: Positioning of the major locus for Puccinia psidii rust resistance (Ppr1) on the Eucalyptus reference map and its validation across unrelated pedigrees. Tree Genetics \& Genomes 2010, 6:953-962.

3. Teixeira JEC, Guedes FTP, Dias DC, Bonine CAV, Camargo LEA: Inheritance of resistance to Puccinia psidii G. Winter in a eucalyptus interspecific hybrid progeny evaluated under conditions of natural infection. Tropical Plant Pathology 2009, 34:203-210.

4. Margarido GRA, Souza AP, Garcia AAF: OneMap: software for genetic mapping in outcrossing species. Hereditas 2007, 144:78-79.

5. Gazaffi R: Desenvolvimento de modelo genético-estatístico para mapeamento de QTLs em progênie de irmãos completos, com aplicação em cana-de-açúcar. PhD Thesis Universidade de São Paulo, Departamento de Genética; 2009.

6. Brondani RPV, Williams ER, Brondani C, Grattapaglia D: A microsatellitebased consensus linkage map for species of Eucalyptus and a novel set of 230 microsatellite markers for the genus. BMC Plant Biology 2006, 6 .

doi:10.1186/1753-6561-5-S7-P32

Cite this article as: Lima et al: Identification of a novel QTL contributing to rust resistance in Eucalyptus. BMC Proceedings 2011 5(Suppl 7):P32.

\section{Submit your next manuscript to BioMed Central and take full advantage of:}

- Convenient online submission

- Thorough peer review

- No space constraints or color figure charges

- Immediate publication on acceptance

- Inclusion in PubMed, CAS, Scopus and Google Scholar

- Research which is freely available for redistribution

Submit your manuscript at www.biomedcentral.com/submit 